\title{
Karst Interest Group 2011
}

\author{
Brian G. Katz
}

Published online: 27 September 2011

(c) Springer-Verlag (outside the USA) 2011

The United States Geological Survey (USGS) Karst Interest Group (KIG) held its fifth triennial meeting at the University of Arkansas in Fayetteville, Arkansas, during April 26-29, 2011. After an interesting keynote presentation by Art Palmer on paleokarst of the USA, oral and poster presentations were given during 2-day sessions on a variety of topics, including karst in coastal zones, geochemistry and contaminant transport in karst systems, karst mapping and GIS, karst program updates, Ozarks plateau karst, karst aquifer systems, karst modeling, karst hydraulics, and geophysical methods in karst. There were 123 people registered for the meeting from government agencies, universities, state, and local agencies.

Goals of the USGS KIG are to encourage and support interdisciplinary collaboration and technology transfer among scientists working in karst areas. The KIG encourages cooperative studies between the different disciplines of the USGS and other Department of Interior agencies and university researchers or research institutes.
Previous KIG meetings were held in St. Petersburg, Florida (2001), Shepherdstown, West Virginia (2002), Rapid City, South Dakota (2005), and Bowling Green, Kentucky (2008). The next meeting is scheduled for 2014 in Carlsbad, New Mexico.

For the 2011 meeting, field trips were organized on the geology and karst landscapes of the Buffalo National River and other karst features in northern Arkansas and southern Missouri. A good time was had by all, despite the recordbreaking rainfall and flooding prior to and during the first 2 days of the meeting.

Proceedings from the 2011 KIG meeting have been published in the U.S. Geological Survey Scientific Investigations Report 2011-5031, which is available on-line at: http://pubs.usgs.gov/sir/2011/5031/.

For additional information about KIG, please visit the KIG website at: http://water.usgs.gov/ogw/karst/kig/ or contact Eve Kuniansky (elkunian@usgs.gov) (770-409-7716).

B. G. Katz $(\square)$

U.S. Geological Survey, Tallahassee, FL 32303, USA

e-mail: bkatz@usgs.gov 